\title{
Identification and bioactivity of native strains of Bacillus thuringiensis from grain-related habitats in Turkey
}

\author{
Özgür Apaydin ${ }^{a}$, Çelenk Çınar ${ }^{a}$, Ferit Turanli ${ }^{b}$, Şebnem Harsa ${ }^{c}$, Hatice Güneş ${ }^{\text {d,* }}$ \\ a Biotechnology Program, Izmir Institute of Technology, Urla Campus, Izmir, Turkey \\ ${ }^{\mathrm{b}}$ Plant Protection Department, Ege University, Bornova Campus, Izmir, Turkey \\ ${ }^{\mathrm{c}}$ Food Engineering Department, Izmir Institute of Technology, Urla Campus, Izmir, Turkey \\ d Biology Department, Muğla University, Kotekli Campus, Muğla TR-48000, Turkey
}

Received 3 July 2007; accepted 15 January 2008

Available online 26 January 2008

\begin{abstract}
A native collection of Bacillus thuringiensis (Bt) strains originated from grain-related habitats in Turkey was characterized according to serotype, cryl gene content, and bioactivity against Ephestia kuehniella (Lepidoptera: Phycitidae) and Spodoptera littoralis (Lepidoptera: Noctuidae). Twenty-three different serotypes as well as 24 unknown serotypes were obtained from 56 positively agglutinated strains with previously characterized antisera. Most common serovars were sotto, kim, and tochigiensis with the percentages of 14, 14, and 13, respectively. Among the cryl gene-positive 36 strains, crylE $(100 \%)$, cryl Aa $(94 \%)$, cryl Ac $(92 \%)$, and crylD $(83 \%)$ genes were the most abundant. Bioactivity tests with $56 \mathrm{Bt}$ strains carrying cry1, cry2, and/or cry 9 genes indicated that all of them resulted in growth retardation or inhibition of larvae of both E. kuehniella and S. littoralis; however, only one strain, 85PPb (serovar morrisoni), caused high mortality in both insects ( $84 \%$ and $100 \%$, respectively). Different crystal morphology was observed for the strain $85 \mathrm{PPb}$ and the standard strain B. thuringiensis subsp. morrisoni. Finally, no correlation was found among serotype, cry gene content and biotoxicity of Bt strains in the collection.
\end{abstract}

(C) 2008 Elsevier Inc. All rights reserved.

Keywords: Bacillus thuringiensis; Serotyping; cryl genes; Bioactivity; Ephestia kuehniella; Spodoptera littoralis

\section{Introduction}

The gram-positive, spore-forming bacterium Bacillus thuringiensis is the most widely used microbial biopesticide. It is also an alternative to synthetic insecticides that often have unintended harmful effects on non-target species. It produces parasporal crystals containing one or more Cry proteins that may be toxic for different insect orders including agriculturally important pests. Cry proteins are encoded by cry genes that are mostly carried on plasmids and to date nearly 300 cry genes have been identified and classified into 51 groups and subgroups on the basis of amino acid sequence similarity (Crickmore et al., 2007).

\footnotetext{
* Corresponding author. Fax: +90 2522238656.

E-mail address: haticegunes@mu.edu.tr (H. Güneș).
}

Worldwide, natural $B$. thuringiensis strains isolated from different habitats are established as $B$. thuringiensis culture collections (Martin and Travers, 1989; Ben-Dov et al., 1997; Bernhard et al., 1997; Bravo et al., 1998; Iriarte et al., 2000; Kim et al., 1998; Hongyu et al., 2000; Uribe et al., 2003). They are important for reflecting biodiversity through sampling sites and finding new strains with high toxicity against target insect species. Strains in the collections are characterized by a number of different methods to identify and to test and confirm their toxicity against different insect orders (Arango et al., 2002; Wang et al., 2003; Tamez-Guerra et al., 2004; Martinez et al., 2005). Identification of cry gene content by PCR is the most effective technique in screening large native collections to predict insecticidal activities of individual strains (Ben-Dov et al., 1997; Porcar and Juarez-Perez, 2002). In addition, serolog- 
ical analysis, biological activity tests, plasmid contents, chromosomal DNA, and protein profiling are used as complementary methods in the search for novel strains.

Based on flagellar H-antigens, Lecadet et al. (1999) reported 69 serotypes of Bt with 82 serovars. At present, this number has reached to 71 serotypes comprising 84 serovars, which can be obtained from the IEBC at the Pasteur Institute (France).

Previously, we reported the first B. thuringiensis collection from different grain-related habitats of the Central Anatolia and the Aegean Region in Turkey and characterized it based on crystal morphology, cry gene content by screening for cryl, cry2, cry3, cry4, and cry9 genes using universal PCR primers, chromosomal, and plasmid DNA patterns (Apaydin et al., 2005). The results indicated a wide range of biodiversity among Bt strains in Anatolia. In this study, we further characterized our collection by serological analysis, cryl gene identification using gene-specific primers, and toxicity tests against the larvae of Mediterranean flour moth, Ephestia kuehniella, and the cotton leaf worm Spodoptera littoralis. In addition, crystal protein morphology of representative strains was investigated.

\section{Materials and methods}

\subsection{Reference and native bacterial strains}

Twelve reference strains were kindly supplied by the following sources: $B$. thuringiensis subsp. kurstaki (HD1), B. thuringiensis subsp. aizawai (HD133), B. thuringiensis subsp. kumamotoensis (HD876 (3-11)), B. thuringiensis biovar. tenebrionis, $B$. thuringiensis serovar israelensis (HD500) by Dr. Daniel R. Zeigler of the Bacillus Genetic Stock Center (Ohio, USA); B. thuringiensis subsp. kyuhuensis (NRRL H4553) and B. thuringiensis subsp. darmstandiensis (NRRL HD-146) by Dr. Alejandro P. Rooney of the ARS Culture Collection (USA); B. thuringiensis subsp. morrisoni, B. thuringiensis subsp. alesti, B. thuringiensis subsp. finitimus, $B$. thuringiensis subsp. galleria, and $B$. thuringiensis subsp. thompsoni by Ege University. One hundred and three native $B$. thuringiensis strains analyzed in this study were previously isolated from soil, grain, stored product dust, straw, insect cadavers and various residues collected from grain silos, caves, crop fields, farms, and haylofts (Apaydin et al., 2005).

\subsection{Motility tests and serological analysis}

Motility of the strains was tested using motility plates $(1 \%(\mathrm{w} / \mathrm{v})$ tryptone, $0.5 \%(\mathrm{w} / \mathrm{v}) \mathrm{NaCl}, 0.3 \%(\mathrm{w} / \mathrm{v})$ agar) as described by Guttmann and Ellar (2000). The strains were streak-inoculated onto the middle of the plate from top to bottom and incubated overnight. If a colony was observed to spread out from the inoculation site, the strain was scored as motile; otherwise it was scored as nonmotile. Serological analysis based on reactivity with flagellar antisera was performed according to a micromethod, using 96-well microtiter plates (U-bottom), as described by Laurent et al. (1996). The whole collection, total 84 antisera (71 serovar and 13 biovar), purchased from the Pasteur Institute (Paris, France) were assayed against the motile isolates to determine the serotypes of grain habitat-originated strains. Bacterial suspensions were prepared by fixation of $5-8 \mathrm{~h}$ cultures grown at $30^{\circ} \mathrm{C}$ with $0.1 \%$ formalin. Initially, all motile strains were screened by two dilutions (1:10 and 1:20) of each antiserum. Bacterial suspensions without antiserum and $150 \mathrm{mM} \mathrm{NaCl}$ in sterile distilled water were used as negative controls. After incubation at $37^{\circ} \mathrm{C}$ for $75 \mathrm{~min}$, agglutination was observed under a white light. A clear supernatant with the floccular sediment at the bottom of the well was scored as positive. Depending on the results of the first screening, if a strain gave a positive reaction with more than one antiserum, it was titrated against lower dilutions (i.e., 1:40, 1:80, 1:160, ...) of these antisera until a positive reaction was obtained for the lowest dilution. Any B. thuringiensis strain not agglutinated by the available antisera in the updated collection was judged to be a potential new serotype (Lecadet et al., 1999).

\subsection{DNA template and PCR analysis}

PCR analysis was used to detect cryl genes encoding Lepidoptera-specific Cry1 proteins. As previously reported, 36 strains of our collection gave positive reaction with the cryl universal primer (Apaydin et al., 2005). In this study, they were screened using gene-specific primers designed to detect the presence of $\operatorname{cryl} A a, \operatorname{cryl} A b$, crylAc, cryl $A d$, $\operatorname{cryl} B, \operatorname{cryl} C, \operatorname{cryl} D, \operatorname{cryl} E, \operatorname{cryl} F$, and $\operatorname{cryl} G$ genes reported by Ceron et al. (1994, 1995). Genomic DNA was isolated according to the method described by Ausubel et al. (1994), and B. thuringiensis subsp. kurstaki (HD1) and B. thuringiensis subsp. aizawai (HD133) served as control strains. Five hundred microgram of genomic DNA was added to the reaction mix, which contained $200 \mu \mathrm{M}$ dNTP, $0.2-0.4 \mu \mathrm{M}$ each of the forward and reverse primer, $1.5 \mathrm{mM} \mathrm{MgCl}_{2}$, and $2 \mathrm{U}$ of Taq DNA polymerase in a volume of $50 \mu \mathrm{l}$. PCR conditions were as follows: a single denaturation step for $5 \mathrm{~min}$ at $95^{\circ} \mathrm{C}$, followed by a 35 amplification cycles including denaturation at $94{ }^{\circ} \mathrm{C}$ for $1 \mathrm{~min}$, annealing at $50^{\circ} \mathrm{C}$ for $\operatorname{cryl} \mathrm{Ab}, \operatorname{cryl} \mathrm{Ac}$, and $\operatorname{crylC}$ genes; $51{ }^{\circ} \mathrm{C}$ for $\operatorname{crylB}$ gene; $53^{\circ} \mathrm{C}$ crylAd and $\operatorname{crylD}$ genes; $54{ }^{\circ} \mathrm{C}$ for $\operatorname{cryl~Aa}$ and cryl $G$ genes; $58{ }^{\circ} \mathrm{C}$ for $\operatorname{cryl} \mathrm{E}$ and $\operatorname{cryl} \mathrm{F}$ genes for $1 \mathrm{~min}$, elongation at $72^{\circ} \mathrm{C}$ for $1 \mathrm{~min}$ and a final extension at $72{ }^{\circ} \mathrm{C}$ for $10 \mathrm{~min}$. Amplifications were carried out in a thermal cycler (Techne Progene, England). After electrophoresis of $10 \mu l$ of each PCR product on $2.5 \%$ agarose-EtBr gel, DNA bands were visualized in a gel documentation system (Vilber Lourmat, France).

\subsection{Bioassay}

In order to evaluate the toxicity of native $B$. thuringiensis strains, first instar larvae of E. kuehniella were used. Spore- 
crystal mixtures were prepared from $56 \mathrm{Bt}$ strains producing Cry1, Cry2, and Cry9 proteins that were reported to be toxic to Lepidopteran insects (Bravo et al., 1998). Bt culture was grown in $100 \mathrm{ml}$ of nutrient broth (NB) at $28^{\circ} \mathrm{C}$ by shaking at $150 \mathrm{rpm}$ for 3 days. Samples were centrifuged at $4{ }^{\circ} \mathrm{C}$ at $6000 \mathrm{rpm}$ for $15 \mathrm{~min}$ and the pellets were washed twice with ice-cold $1 \mathrm{M} \mathrm{NaCl}$ and three times with cold sterile distilled water. The pellets were dried overnight at $37-40^{\circ} \mathrm{C}$, weighed and stored as powder at $-20^{\circ} \mathrm{C}$ until used. Neonates of $E$. kuehniella were kindly supplied by the Agricultural Research Institute, Plant Protection Department (İzmir, Turkey). The spore-crystal powders were suspended in distilled water containing $0.1 \%$ Tween 80 . Suspensions were mixed with a diet that included wheat/corn powder (2:1) at the concentration of $20 \mathrm{ppm}$ (i.e., $100 \mu \mathrm{g}$ of spore-crystal mixture in $5 \mathrm{~g} \mathrm{com}$ post) and dried. For some of the strains two higher doses (200 and $2000 \mathrm{ppm}$ ) were also applied to confirm their toxicity. Assays were performed using 25 larva per dose with three replicates. B. thuringiensis subsp. kurstaki (HD-1) or subsp. aizawai (HD-133) and the diet without toxin served as positive and negative controls, respectively. Toxicity tests were carried out at $25^{\circ} \mathrm{C}, 70 \% \mathrm{RH}$ with $16: 8 \mathrm{~h}$, L:D schedule; and larval growth and mortality was recorded after 14 days.

In addition, toxicity of Bt strains was tested against $S$. littoralis (Lepidoptera; Noctuidae), a species that causes considerable economic loss throughout Southeastern Europe, Africa, and Asia. Insects were reared on a premixed diet based on alfalfa powder and agar (Stonefly Industries, USA) at $20-23{ }^{\circ} \mathrm{C}$ and $16: 8 \mathrm{~h}$ (light to dark) photoperiod for 10-15 generations. Bt toxins were added to the diet at the ratio of $100 \mu \mathrm{g}$ toxin in $5 \mathrm{~g}$ compost and applied to the penultimate instars larvae of $S$. littoralis via food. Then, larval growth and mortality were monitored for 16 days.

\subsection{Electron microscopy}

Spore and crystal morphologies of representative $B$. thuringiensis strains were investigated by SEM. A loop of Bt culture, grown on NA plates for $72 \mathrm{~h}$, was suspended in $1 \mathrm{ml}$ of distilled water. After centrifugation at $5000 \mathrm{rpm}$ for $15 \mathrm{~min}$, the pellet was resuspended in $0.5 \mathrm{M}$ $\mathrm{NaCl}$ to remove cell residues and incubated at $37^{\circ} \mathrm{C}$ for $30 \mathrm{~min}$. The suspension was centrifuged at $10,000 \mathrm{rpm}$ for $10 \mathrm{~min}$ and the pellet was washed three times with distilled water. Then, a $10-\mu l$ of aliquot of the spore-crystal mixture dissolved in $1 \mathrm{ml}$ of distilled water was placed on a microscope lid. After drying at $37^{\circ} \mathrm{C}$ for $3 \mathrm{~h}$, the sample was coated with gold and examined under the electron microscope (Philips XL 30 SFEG) at $5 \mathrm{kV}$.

\section{Results}

\subsection{Motility evaluation and serological distribution of $B$. thuringiensis strains}

All 103 native $B$. thuringiensis strains were subjected to motility test prior to serotyping. Motility was evaluated based on the expansion size of the colonies from the inoculation site. Eighty-four strains were judged to be motile to varying degrees. Of the 84 strains, 13 were very motile $(++++), 26$ were motile $(+++), 17$ were slightly motile $(++)$, and 28 were poorly motile $(+)$. The remaining 19 strains were scored as non-motile.

When the motile 84 B. thuringiensis strains were titrated against 71 antisera, 56 strains yielded positive agglutination, 4 strains showed autoagglutination, and 24 strains showed no agglutination (Table 1). Among the motile strains, 23 different serovars were identified. Even though the serovars sotto $(14 \%)$, kim $(14 \%)$, and tochigiensis $(13 \%)$ were the most abundant in the collection, the serovars canadensis, nigeriensis, toumanoffi, kyushuensis, indiana, yunnanensis, shandongiensis, mexicanensis, leesis, muju, xiaguengiensis, and jordanica were represented only by a single strain (Table 1). The remaining 24 isolates gave no agglutination with the antisera used, and they are classified as 'unknown serotype'.

\subsection{Identification of cryl gene composition}

Thirty-six B. thuringiensis strains were initially identified as cryl gene-positive with a generic oligonucleotide primer. A more detailed characterization of these strains was carried out using gene-specific primers for 10 cryl genes: cryl Aa, cryl $A b, \operatorname{cryl} A c, \operatorname{cryl} A d, \operatorname{cryl} B, \operatorname{cryl} C, \operatorname{cryl} D, \operatorname{cryl} E, \operatorname{cryl} F$, and $\operatorname{cry} 1 G$. All native $B$. thuringiensis strains were positive for more than one cryl gene ranging from two to nine, and 18 different cryl gene profiles were obtained (Table 2). The $\operatorname{crylE}(100 \%)$ gene detected in all strains was the most frequent one followed by cryl Aa $(95 \%)$, cryl Ac $(91 \%)$, and crylD (83\%) genes (Fig. 1). The genes crylC (67\%), crylG $(58 \%)$, and $\operatorname{cryl} F(52 \%)$ were moderately frequent, whereas $\operatorname{crylB}(3 \%)$, crylAd $(6 \%)$, and $\operatorname{cryl} A b(7 \%)$ were the least common genes (Fig. 1).

\subsection{Biological activities of B. thuringiensis strains}

The insecticidal toxicity of 56 native $B$. thuringiensis strains was investigated against first instar larva of $E$. kuehniella. Among the strains, $80 \%$ of the isolates showed varying degrees of toxicity, whereas $20 \%$ of the isolates were not toxic (Table 3). About half of the native strains $(44.6 \%)$ caused mortality between $10 \%$ and $30 \%$. In addition, the mortality range of 13 strains was lower than $10 \%$; and that of 6 strains was moderate $(30-50 \%)$. However, only one strain $(85 \mathrm{PPb})$ showed very high toxicity ( $84 \%$ mortality). In all tests, the mortality obtained from the control strain B. thuringiensis subsp. kurstaki varied from $91 \%$ to $100 \%$. In addition to having variation in toxic activity at different ranges, nearly all strains retarded the growth rate of the larva and most of them prevented the larva from entering the pupae stage (data not shown).

Furthermore, B. thuringiensis strains exhibiting variable toxicity on E. kuehniella were also tested against $S$. littoralis using the single-dose assay. Similar to the results from $E$. 
Table 1

Serotyping of B. thuringiensis isolates with flagellar based $\mathrm{H}$ antigens ( $\mathrm{H} 1-\mathrm{H} 71)$

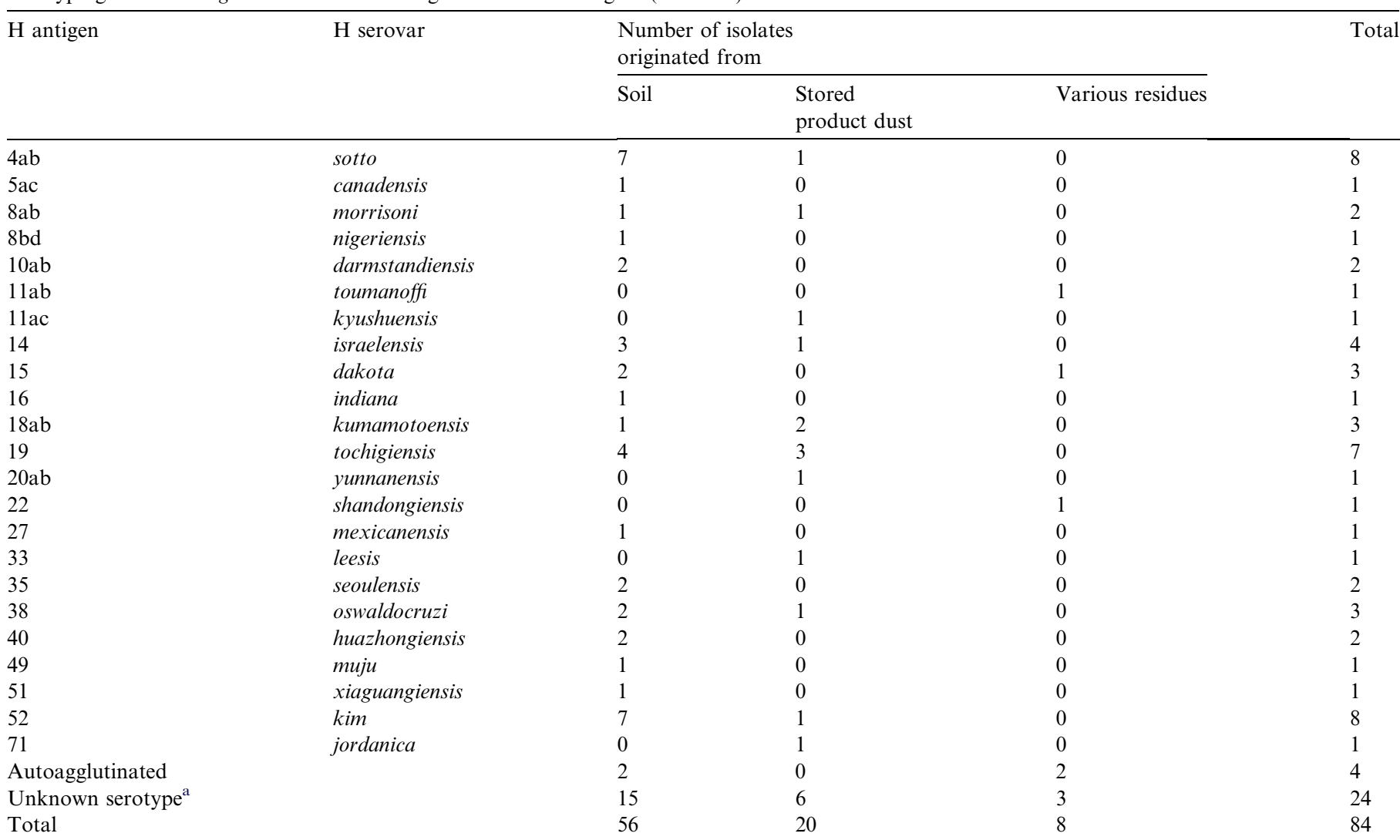

${ }^{\text {a }}$ Motile isolates but gave no agglutination with known reference antisera.

Table 2

cryl gene profile of $B$. thuringiensis strains

\begin{tabular}{|c|c|c|}
\hline Profile & cryl gene content & Name of isolate \\
\hline 1 & $\operatorname{cry} 1 C, \operatorname{cry} l E$ & $57 \mathrm{Hb}$ \\
\hline 2 & $\operatorname{cry} 1 A a, \operatorname{cry} 1 A c, \operatorname{cry} 1 E$ & $24 \mathrm{Fa}$ \\
\hline 3 & $\operatorname{cryl} A, \operatorname{cry} 1 D$, crylE, $\operatorname{cryl} G$ & $5 \mathrm{Ca}$ \\
\hline 4 & $\operatorname{cryl} A a, \operatorname{cryl} A c, \operatorname{cryl}$, $\operatorname{cry} l G$ & $7 \mathrm{Bb}$ \\
\hline 5 & $\operatorname{cryl} A a, \operatorname{cryl} A c, \operatorname{cryl} 1, \operatorname{cryl} E$ & $28 \mathrm{Aa}$ \\
\hline 6 & $\operatorname{cryl} A a$, cryl $A c$, crylE, $\operatorname{cryl} F$ & $28 \mathrm{Ca}$ \\
\hline 7 & cryl $A a$, cryl $A c$, crylD, $\operatorname{cry} 1 E$, crylF & $11 \mathrm{Ka}, 13 \mathrm{La}, 35 \mathrm{~Kb}$ \\
\hline 8 & $\operatorname{cryl} A a, \operatorname{cryl} A c, \operatorname{cry} l C, \operatorname{cry} l D, \operatorname{cryl} E$ & $25 \mathrm{~Pb}, 33 \mathrm{Yb}, 55 \mathrm{Ka}, 60 \mathrm{Na}$ \\
\hline 9 & cryl $A a$, cryl $A d$, crylD, $\operatorname{cry} l E$, crylF & $48 \mathrm{Ra}$ \\
\hline 10 & $\operatorname{cryl} A a$, cryl $C$, crylE, $\operatorname{cryl} F$, crylG & $102 \mathrm{Fb}$ \\
\hline 11 & $\operatorname{cryl} A a, \operatorname{cry} l A c, \operatorname{cry} l C, \operatorname{cryl} D, \operatorname{cry} l E, \operatorname{cry} l F$ & $1 \mathrm{Aa}, 28 \mathrm{Lb}$ \\
\hline 12 & $\operatorname{cryl} A a, \operatorname{cryl} A c, \operatorname{cry} l C, \operatorname{cry} l D, \operatorname{cry} l E, \operatorname{cry} l G$ & $1 \mathrm{Cb}, 7 \mathrm{Fa}, 27 \mathrm{~Pb}, 39 \mathrm{Yb}, 59 \mathrm{Ya}, 71 \mathrm{Lb}, 107 \mathrm{Fa}$ \\
\hline 13 & $\operatorname{cry} 1 A a, \operatorname{cry} 1 A c, \operatorname{cry} 1 D, \operatorname{cry} 1 E, \operatorname{cry} 1 F, \operatorname{cry} 1 G$ & $25 \mathrm{Fb}, 71 \mathrm{Na}$ \\
\hline 14 & $\operatorname{cry} 1 A a, \operatorname{cry} 1 A c, \operatorname{cry} 1 A d, \operatorname{cry} 1 D, \operatorname{cry} 1 E, \operatorname{cry} 1 G$ & $35 \mathrm{~Pb}$ \\
\hline 15 & $\operatorname{cryl} A a, \operatorname{cry} l A c, \operatorname{cry} l C, \operatorname{cryl} l E, \operatorname{cry} l F$, cryl $G$ & $43 \mathrm{Db}$ \\
\hline 16 & cryl $A a$, cryl $A c$, crylC, $\operatorname{cry} 1 D$, crylE, $\operatorname{cry} l F$, crylG & $1 \mathrm{Ab}, 4 \mathrm{Cb}, 24 \mathrm{La}, 25 \mathrm{Ua}, 39 \mathrm{Ya}$ \\
\hline 17 & 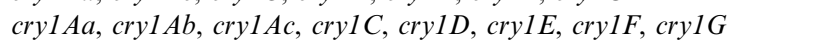 & $58 \mathrm{~Kb}, 93 \mathrm{Fa}$ \\
\hline 18 & $\operatorname{cry} 1 A a, \operatorname{cry} 1 A b, \operatorname{cry} 1 A c, \operatorname{cry} 1 B, \operatorname{cry} 1 C, \operatorname{cry} 1 D, \operatorname{cry} 1 E, \operatorname{cry} 1 F, \operatorname{cry} l G$ & $85 \mathrm{PPb}$ \\
\hline
\end{tabular}

kuehniella, only one strain $(85 \mathrm{PPb})$ showed high toxicity against $S$. littoralis (Fig. 2). In the absence of toxin, larval weight of $S$. littoralis reached to $850 \mathrm{mg}$ at day 6 and 7 . However, toxin from $85 \mathrm{PPb}$ (serovar morrisoni) or B. thruringiensis subsp. aizawai prevented the larval growth $100 \%$ throughout the test period.

\subsection{Crystal protein morphology}

Two native strains, $85 \mathrm{PPb}$ and $43 \mathrm{Fa}$, and a reference strain $B$. thuringiensis subsp. morrisoni were examined with SEM for crystal protein morphology. Spore-crystal preparations were made from $72-\mathrm{h} B$. thuringiensis cultures. As 


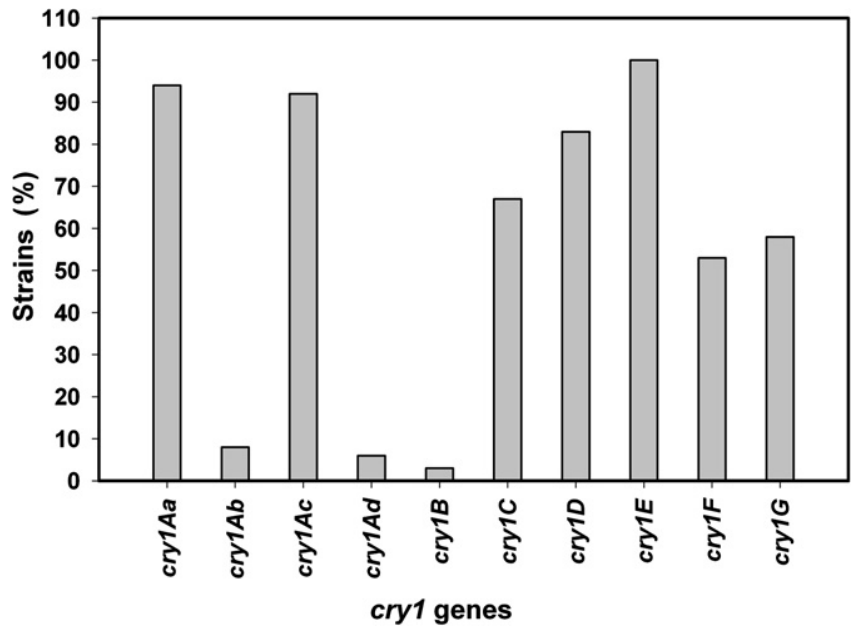

Fig. 1. cryl genotype distribution of $B$. thuringiensis strains.

shown clearly in Fig. 3, 85 $\mathrm{PPb}$ produced bipyramidal crystal proteins, consistent with the presence of Cryl protein. Similarly, B. thuringiensis subsp. morrisoni produced bipyramidal and/or rectangular proteins indicating the expression of Cry1 and Cry2 proteins (López-Meza and Ibarra, 1996).

\section{Discussion}

In this study, B. thuringiensis collection from grainrelated habitats in Turkey was characterized with respect to serology, cryl specific gene content and insecticidal toxicity. In addition, protein profiles and crystal protein morphologies of the most toxic strain and related reference strains were analyzed.

A great deal of serological diversity was found among $B$. thuringiensis strains included in this study. In total, 23 different serovars were identified among 56 of the 84 motile strains (Table 1). Martinez et al. (2005) reported 19 serovars among 178 B. thuringiensis strains native to Spain. Interestingly, serotypes were unevenly distributed through

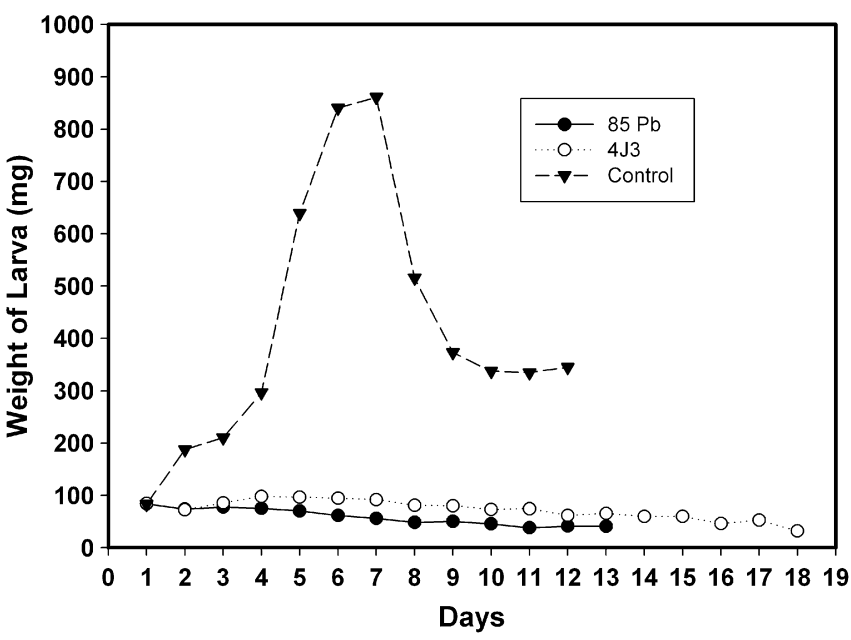

Fig. 2. Effects of $B$. thuringiensis strains on growth of $S$. littoralis (penultimate instar). The larvae were fed with diet including $20 \mathrm{ppm} B$. thuringiensis spore-crystal mixture and the larval growth was weighed every day during the test period. Figure indicates larval development in the control (without any toxins) and in the diet containing crystal-spore mixture of a reference strain B. thuringiensis subsp. aizawai (4J3) and a native strain $85 \mathrm{PPb}$ (serovar morrisoni).

the collection, and one type, aizawai, was present in nearly $50 \%$ of the strains. Unlike in their findings, we did not observe predominance of a particular type among our strains. In fact, we observed a regular distribution of serovars in our collection, where the number of strains varied from one to eight (Table 1). Moreover, Martin and Travers (1989) reported the serovar kurstaki as the most common type in Asia, whereas the serovar israelensis was most common in Europe and the United States. Similarly, Mizuki et al. (1999) found the serovar kurstaki to be the predominant on the phylloplanes in Japan. Another study from Asia also reported israelensis and kurstaki as the most frequent types in Jordanian habitats (Al-Momani et al., 2004). However, none of the strains in our collection was identified as kurstaki and the strains sotto (14\%), $\mathrm{kim}(14 \%)$, tochigiensis (13\%), and israelensis (7\%) were the most abun-

Table 3

Toxicity of native $B$. thuringiensis strains against E. Kuehniella

\begin{tabular}{lll}
\hline Toxicity $^{*}$ & Name of Bt isolate & Percentage \\
\hline Non-toxic $^{\mathrm{a}}$ & $25 \mathrm{Fb}, 93 \mathrm{Fa}, 28 \mathrm{Lb}, 71 \mathrm{Lb}, 4 \mathrm{Cb}, 28 \mathrm{Ca}$, & $19.6(11)^{\mathrm{b}}$ \\
& $34 \mathrm{Bb}, 18 \mathrm{Fa}, 8 \mathrm{Ba}, 62 \mathrm{PPa}, 24 \mathrm{Fb}$ & \\
$\leqslant 10 \%$ & $48 \mathrm{Ra}, 71 \mathrm{Na}, 13 \mathrm{La}, 58 \mathrm{~Kb}, 60 \mathrm{Na}, 19 \mathrm{Rb}$, & $23.2(13)^{\mathrm{b}}$ \\
& $87 \mathrm{Fb}, 43 \mathrm{Fa}, 18 \mathrm{FFa}, 1 \mathrm{Bb}, 35 \mathrm{~Kb}, 27 \mathrm{Cb}, 82 \mathrm{YYb}$ & \\
$10-30 \%$ & $35 \mathrm{~Pb}, 39 \mathrm{Yb}, 11 \mathrm{Ka}, 5 \mathrm{Ca}, 1 \mathrm{Ab}, 107 \mathrm{Fa}, 25 \mathrm{Ua}$, & $44.6(25)^{\mathrm{b}}$ \\
& $1 \mathrm{Aa}, 27 \mathrm{~Pb}, 93 \mathrm{Ha}, 24 \mathrm{La}, 27 \mathrm{Fb}, 57 \mathrm{Hb}, 19 \mathrm{Hb}$, & \\
$30-50 \%$ & $20 \mathrm{Rb}, 13 \mathrm{Nb}, 2 \mathrm{Ib}, 26 \mathrm{Ba}, 27 \mathrm{Fa}, 4 \mathrm{Cb}, 1 \mathrm{Cb}, 24 \mathrm{Lb}, 93 \mathrm{FFa}, 23 \mathrm{Ba}, 27 \mathrm{Ka}$ & $10.7(6)^{\mathrm{b}}$ \\
$\geqslant 50 \%$ & $25 \mathrm{~Pb}, 43 \mathrm{Db}, 24 \mathrm{Fa}, 1 \mathrm{CCb}, 93 \mathrm{Da}, 7 \mathrm{Bb}$ & \\
Total & $85 \mathrm{PPb}$ & \\
\hline
\end{tabular}

* One dose $(100 \mathrm{ppm})$ assay against first instar larvae of E. kuehniella.

${ }^{a}$ Isolates causing no mortality but slowing down the growth rate of larvae.

${ }^{\mathrm{b}}$ Number of $B$. thuringiensis isolates. 

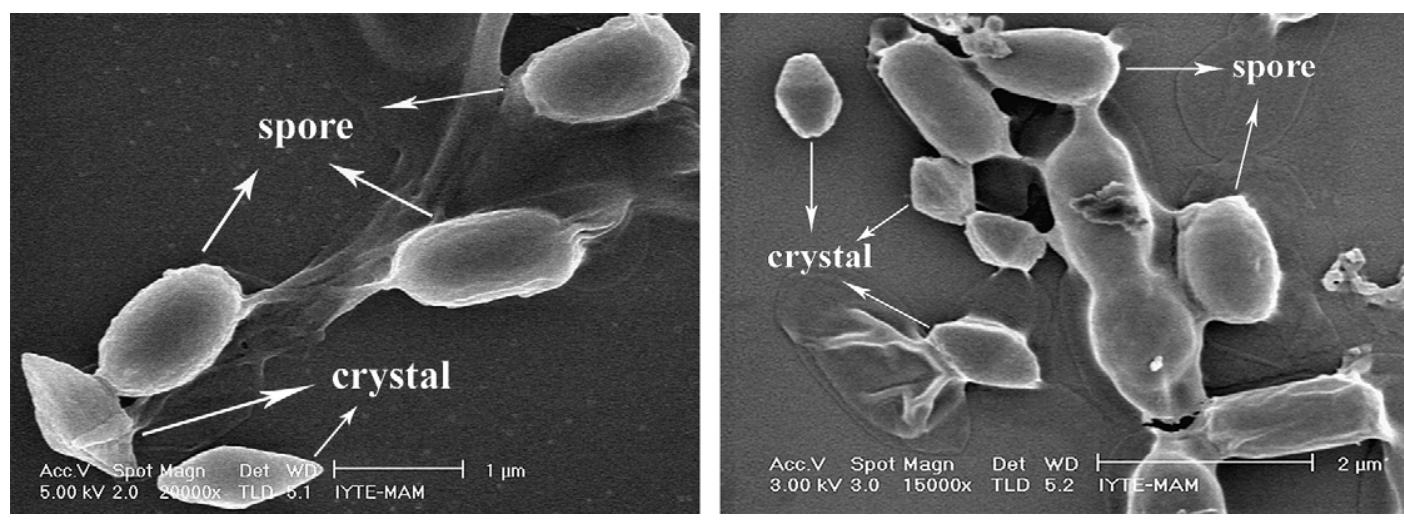

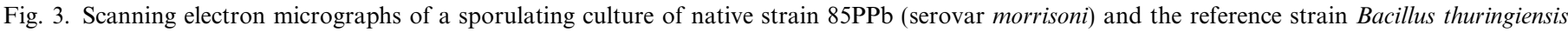
subsp. morrisoni.

dant (Table 1). Twenty-four of 84 motile B. thuringiensis strains did not react with any of the 71 antisera tested and thus grouped as the 'unknown serotype'.

Toxic potency of $B$. thuringiensis strains depends on the type and subgroups of cry genes. Lambert et al. (1996) reported that Cry1Ab5 protein had greater toxicity against $H$. armigera (Lepidoptera) than Cry1Acl protein. Therefore, it is important to identify the subgroups of cry genes using gene-specific oligonucleotide primers. The PCR identification of cryl-type genes of 36 strains in the present study yielded 18 different profiles from the combinations of two to nine different cryl genes (Table 2). Martinez et al. (2005) analyzed 152 B. thuringiensis strains, native to Spain, based on 12 cryl and one cry 2 genes and they obtained 81 different profiles from combination of one to ten different genes. In another study from Colombia, Uribe et al. (2003) reported 30 different profiles of 137 strains screened for 8 cryl-type genes, each harboring one to six different genes.

In addition, we found that, $\operatorname{cry} l E, \operatorname{cry} l A a, c r y l A c$, and crylD were the most common genes, whereas crylB, $c r y l A d$, and $c r y l A b$ were the least common among the strains analyzed (Fig. 1). However, Bravo et al. (1998) found $\operatorname{cryl} A, \operatorname{cryl} B, \operatorname{cry} l C$, and $\operatorname{cry} 1 D$ genes more common than $\operatorname{cry} l E$ and $\operatorname{cry} l F$ in Mexican Bt strains. Moreover, Martinez and Caballero (2002) reported that cryl $A a$ and $c r y l A b$ were more abundant than crylAd, cry $1 E$, cry $1 F$, and crylG genes in B. thuringiensis strains collected from aquatic and terrestrial habitats of Spain. Taken together, these results indicate that the distribution of $c r y 1$ genes differs in collections depending on the origin of $B$. thuringiensis strains.

Martinez et al. (2005) and Martinez and Caballero (2002) reported that the distribution of cryl genes somewhat correlated with particular serovars. They carried out statistical analysis to see the relation between serotype and cryl gene frequency because the number of strains were relatively high for each type of cryl gene, ranging from 8 to 80 . However, the lower number of our strains for each cryl gene, ranging from 1 to 8 , did not allow us to do statistical analysis for distribution of $\operatorname{cry} 1$ genotypes among serotypes. Nevertheless, it was noticed that the combination of cryl genes within the same serovar and/ or among different serovars was very different (data not shown). This may be due to the plasmid transfer specificity of cryl genes among serovars or strains of the same serovar. Additionally, less frequent ( $1 \%$ ) cry $1 B$ gene was only observed in the serovar morrisoni, the most toxic isolate.

Bioactivity tests revealed that most of the strains were toxic to E. kuehniella yielding different mortality levels (Table 3). Only one strain $(85 \mathrm{PPb})$ identified as serovar morrisoni caused a high level of mortality (84\%) and was positive for cryl and cry 2 genes. It was also the only strain harboring nine cryl genes including crylAa, cryl $A b$, $\operatorname{cry} l A c, \operatorname{cry} l B, \operatorname{cry} l C, \operatorname{cry} l D, \operatorname{cry} l E, \operatorname{cry} l F$, and $\operatorname{cry} l G$ among all $B$. thuringiensis strains tested. Similarly, a novel B. thuringiensis strain (serovar kurstaki) isolated from Tunisian soil was reported to be toxic to lepidopteran insects including E. kuehniella due to Cry1Aa, Cry1Ac, and Cry2Aa proteins (Tounsi et al., 1999, 2003; Tounsi and Jaoua, 2002, 2003). Similar to their results, cryl Aa and $\operatorname{cry} l A c$ were the second and third most abundant genes, respectively, among the strains analyzed in the present study and some of the strains were positive for cry 2 gene as well. Even though there was a similar gene content, only one highly toxic strain was identified. This might have resulted from such factors as the cry gene combinations, expression of related genes at the protein level and possible synergy among cry genes. On the other hand, nearly all strains led to retarded larval growth, and some prevented the larva from entering the pupae stage. In terms of the protection of ecological balance in the environment, less toxic strains may become more important biological control agents in the future.

Similar toxic effect of $B$. thuringiensis isolates was also observed on the $S$. littoralis (data not shown) and the most toxic strain was found to be $85 \mathrm{PPb}$. In addition to $8 \mathrm{cry} 1$ gene subgroups, presence of $c r y 1 \mathrm{C}$ in the $85 \mathrm{PPb}$ is in agreement with the results of Escriche et al. (1998) who showed that some of the Cryl insecticidal crystal proteins, especially CrylCa, that is active against $S$. littoralis, made brush border membrane vesicles permeable to KCI. More- 
over, Polanczyk et al. (2000) examined the effects of different $B$. thuringiensis strains on the $S$. frugiperda larvae. In agreement with their results, we found that $B$. thuringiensis aizawai and $85 \mathrm{PPb}$ were the most toxic $(100 \%)$ strains against $S$. littoralis compared to other serovars, and $B$. thuringiensis kurstaki exhibited the same effect with the control containing no toxin (data not shown).

In conclusion, 23 different serovars and 24 unknown serotypes were identified among $103 \mathrm{~B}$. thuringiensis strains collected from grain-related habitats in Turkey. Furthermore, cryl gene content of 36 isolates was greatly variable within and/or among serovars. Moreover, most of the strains caused less than $50 \%$ mortality in E. kuehniella; however, one strain, $85 \mathrm{PPb}$, was found to be highly toxic to E. kuehniella $(84 \%)$ and S. littoralis $(100 \%)$. Finally, there was no correlation among serotype, cry gene content, and toxicity of the isolates, indicating a great biodiversity of B. thuringiensis strains in Turkey. Future studies including detailed bioactivity assays on different pests, sequencing and transfection of toxin genes are likely to show the strain $85 \mathrm{PPb}$ as a potential biopesticide that originated from Central Anatolia.

\section{Acknowledgments}

We thank Dr. Mehmet Ali Göven and Dr. Bilgin Güven at the Plant Protection Department in Agricultural Research Institute, IZMIR, for their assistance with insect culture. This work was supported by a grant from Turkish Republic, State Planning Organization, DPT (2002K-120/ 390).

\section{References}

Al-Momani, F., Obeidat, M., Saadoun, I., Meqdam, M., 2004. Serotyping of Bacillus thuringiensis isolates, their distribution in different Jourdanian habitats and pathogenicity in Drosophila melanogaster. World Journal of Microbiology \& Biotechnology 20, 749-753.

Apaydin, Ö., Yenidünya, A.F., Harsa, Ş., Güneş, H., 2005. Isolation and characterization of Bacillus thuringiensis strains from different grain habitats in Turkey. World Journal of Microbiology \& Biotechnology 21, 285-292.

Arango, J.A., Romero, M., Orduz, S., 2002. Diversity of Bacillus thuringiensis strains from Colombia with insecticidal activity against Spodoptera frugiperda (Lepidoptera: Noctuidae). Journal of Applied Microbiology 92, 466-474.

Ausubel, F.M., Brent, R., Kingston, R.E., Moore, D.D., Seidman, J.G., Smith, J.A., Struhl, K., 1994. Current Protocols in Molecular Biology 3. John Wiley \& Sons Inc., New York, Chapter 2.

Ben-Dov, E., Zaritsky, A., Dahan, E., Barak, Z., Sinai, R., Manasherob, R., Khamraev, A., Troitskaya, E., Dubitsky, A., Berezina, N., Margalith, Y., 1997. Extended screening by PCR for seven cry-group genes from field collected strains of Bacillus thuringiensis. Applied and Environmental Microbiology 63, 4883-4890.

Bernhard, K., Jarrett, P., Meadows, M., Butt, J., Ellis, D.J., Roberts, G.M., Pauli, S., Rodgers, P., Burges, H.D., 1997. Natural isolates of Bacillus thuringiensis: worldwide distribution, characterization, and activity against insect pests. Journal of Invertebrate Pathology 70, 5968.

Bravo, A., Sarabia, S., Lopez, L., Ontiveros, H., Abarca, C., Ortiz, A., Ortiz, M., Lina, L., Villaloboz, F.J., Peña, G., Nuñez-Valdez, M.E.,
Soberon, Quintero, R., 1998. Characterization of cry genes in a Mexican Bacillus thuringiensis strain collection. Applied and Environmental Microbiology 64, 4965-4972.

Ceron, J., Covarrubias, L., Quintero, R., Ortiz, A., Ortiz, M., Aranda, E., Lina, L., Bravo, A., 1994. PCR analysis of the cryI insecticidal crystal family genes from Bacillus thuringiensis. Applied and Environmental Microbiology 60, 353-356.

Ceron, J., Ortiz, A., Quintero, R., Guereca, L., Bravo, A., 1995. Specific PCR primers directed to identify cryI and cryIII genes within a Bacillus thuringiensis strain collection. Applied and Environmental Microbiology $61,3826-3831$.

Crickmore, N., Zeigler, D.R., Feitelson, J., Schnepf, E., Van-Rie, J., Lereclus, D., Baum, J., Dean, D.H., 2007. Bacillus thuringiensis toxin nomenclature. Available from: <http://www.lifesci.sussex.ac.uk/ Home/NeilCrickmore/Bt/>.

Escriche, B., Decker, D., Van rie, J., Jansens, S., Van Kerhove, E., 1998. Changes in permeability of brush border membrane vesicles from Spodoptera littoralis midgut induced by insecticidal crystal proteins from Bacillus thuringiensis. Applied and Environmental Microbiology 64, 1563-1565.

Guttmann, D.M., Ellar, D.J., 2000. Phenotypic and genotypic comparisons of 23 strains from the Bacillus cereus complex for a selection of known and putative $B$. thuringiensis virulence factors. FEMS Microbiology Letters 188, 7-13.

Hongyu, Z., Ziniu, Y., Wangxi, D., 2000. Composition and ecological distribution of cry proteins and their genotypes of Bacillus thuringiensis isolates from warehouses in China. Journal of Invertebrate Pathology 76, 191-197.

Iriarte, J., Porcar, M., Lecadet, M.M., Caballero, P., 2000. Isolation and characterization of Bacillus thuringiensis strains from aquatic environments in Spain. Current Microbiology 40, 402-408.

Kim, H.S., Lee, D.W., Woo, S.D., Yu, Y.M., Kang, S.K., 1998. Distribution, serological identification, and PCR analysis of Bacillus thuringiensis isolated from soils of Korea. Current Microbiology 37, 195-200.

Lambert, B., Buysse, L., Decock, C., Jansens, S., Piens, C., Saey, B., Seurinck, J., Van Audenhove, K., Van Rie, J., Van Vliet, A., Peferoen, M., 1996. A Bacillus thuringiensis insecticidal crystal protein with a high activity against members of the family Noctuidae. Applied and Environmental Microbiology 62, 80-86.

Laurent, P., Ripouteau, H., Cosmao Dumanoir, V., Frachon, E., Lecadet, M.-M., 1996. A micromethod for serotyping Bacillus thuringiensis. Letters in Applied Microbiology 22, 259-261.

Lecadet, M.-M., Frachon, E., Cosmao Dumanoir, V., Ripouteau, H., Hamon, S., Laurent, P., Thiéry, I., 1999. Updating the H-antigen classification of Bacillus thuringiensis. Journal of Applied Microbiology $86,660-672$.

López-Meza, J.E., Ibarra, J.E., 1996. Characterization of a novel strain of Bacillus thuringiensis. Applied and Environmental Microbiology 62, 1306-1310.

Martin, P.W., Travers, R.S., 1989. Worldwide abundance and distribution of Bacillus thuringiensis isolates. Applied and Environmental Microbiology 55, 2437-2442.

Martinez, C., Caballero, P., 2002. Contents of cry genes and insecticidal toxicity of Bacillus thuringiensis strains from terrestrial and aquatic habitats. Journal of Applied Microbiology 92, 745-752.

Martinez, C., Ibarra, J.E., Caballero, P., 2005. Association analysis between serotype, cry gene content, and toxicity to Helicoverpa armigera larvae among Bacillus thuringiensis isolates native to Spain. Journal of Invertebrate Pathology 90, 91-97.

Mizuki, E., Ichimatsu, T., Hwang, S.H., Park, Y.S., Saitoh, H., Higuchi, K., Ohba, M., 1999. Ubiquity of Bacillus thuringiensis on phylloplanes of arboreous and herbaceous plants in Japan. Journal of Applied Microbiology 86, 979-984.

Polanczyk, R.A., Pires da Silva, R.F., Fiuza, L.M., 2000. Effectiveness of Bacillus thuringiensis strains against Spodoptera frugiperda (Lepidoptera: Noctuidae), Brazil. Journal of Microbiology 31, 165-167. 
Porcar, M., Juarez-Perez, V., 2002. PCR-based identification of Bacillus thuringiensis pesticidal crystal genes. FEMS Microbiology Reviews $757,1-4$.

Tamez-Guerra, P., Iracheta, M.M., Pereyra-Alférez, B., Galán-Wong, L.J., Gomez-Flores, R., Tamez-Guerra, R.S., Rodríguez-Padilla, C., 2004. Characterization of Mexican Bacillus thuringiensis strains toxic for lepidopteran and coleopteran larvae. Journal of Invertebrate Pathology 86, 7-18.

Tounsi, S., J'Mal, A., Zouari, N., Jaoua, S., 1999. Cloning and nucleotide sequence of a novel cry1Aa-type gene from Bacillus thuringiensis subsp. kurstaki. Biotechnology Letters 21, 771-775.

Tounsi, S., Jaoua, S., 2002. Identification of a promoter for the crystal protein-encoding gene crylIa from Bacillus thuringiensis subsp. kurstaki. FEMS Microbiology Letters 208, 215-218.
Tounsi, S., Jaoua, S., 2003. Characterization of a novel cry2Aa-type gene from Bacillus thuringiensis subsp. kurstaki. Biotechnology Letters 25, 1219-1223.

Tounsi, S., Zouari, N., Jaoua, S., 2003. Cloning and study of the expression of a novel cry1Aa-type gene from Bacillus thuringiensis subsp. kurstaki. Journal of Applied Microbiology 94, 1-6.

Uribe, D., Martinez, W., Cerón, J., 2003. Distribution and diversity of cry genes in native strains of Bacillus thuringiensis obtained from different ecosystems from Colombia. Journal of Invertebrate Pathology 82, $119-127$

Wang, J., Boets, A., Van Rie, J., Ren, G., 2003. Characterization of cryl, cry2, cry9 genes in Bacillus thuringiensis isolates from China. Journal of Invertebrate Pathology 82, 63-71. 